\title{
Clinical Features, Diagnosis, and Treatment of COVID-19 in Hospitalized Patients: A Systematic Review of Case Reports and Case Series
}

\begin{abstract}
Azin Tahvildari ${ }^{1+}$, Mahta Arbabi ${ }^{1 \dagger}$, Yeganeh Farsi ${ }^{1+}$, Parnian Jamshidi ${ }^{1 \dagger}$, Saba Hasanzadeh ${ }^{1 \dagger}$, Tess Moore Calcagno ${ }^{2 \dagger}$, Mohammad Javad Nasiri ${ }^{3 *}$ and Mehdi Mirsaeidi ${ }^{2 *}$
\end{abstract}

OPEN ACCESS

Edited by:

Zisis Kozlakidis,

International Agency for Research on

Cancer (IARC), France

Reviewed by:

Patrick Alexander Wachholz, São Paulo State University, Brazil Meng Rui Lee,

National Taiwan University, Taiwan

*Correspondence: Mohammad Javad Nasiri

mi.nasiri@hotmail.com Mehdi Mirsaeid

msm249@med.miami.edu

${ }^{+}$These authors have contributed equally to this work and share first authorship

Specialty section:

This article was submitted to Infectious Diseases - Surveillance,

Prevention and Treatment, a section of the journal

Frontiers in Medicine

Received: 03 April 2020 Accepted: 04 May 2020 Published: 15 May 2020

Citation:

Tahvildari A, Arbabi M, Farsi Y, Jamshidi P. Hasanzadeh S,

Calcagno TM, Nasiri MJ and Mirsaeidi M (2020) Clinical Features, Diagnosis, and Treatment of COVID-19 in Hospitalized Patients: A Systematic Review of Case Reports and Case Series. Front. Med. 7:231.

doi: 10.3389/fmed.2020.00231
'Student Research Committee, School of Medicine, Shahid Beheshti University of Medical Sciences, Tehran, Iran,
${ }^{2}$ Department of Microbiology, School of Medicine, Shahid Beheshti University of Medical Sciences, Tehran, Iran, ${ }^{3}$ Division of
Pulmonary, Critical Care, Sleep and Allergy, Department of Medicine, Miller School of Medicine, University of Miami, Miami, FL, United States

Introduction: The 2019 novel coronavirus (COVID-19) has been declared a public health emergency worldwide. The objective of this systematic review was to characterize the clinical, diagnostic, and treatment characteristics of hospitalized patients presenting with COVID-19.

Methods: We conducted a structured search using PubMed/Medline, Embase, and Web of Science to collect both case reports and case series on COVID-19 published up to April 24, 2020. There were no restrictions regarding publication language.

Results: Eighty articles were included analyzing a total of 417 patients with a mean age of 48 years. The most common presenting symptom in patients who tested positive for COVID-19 was fever, reported in up to $62 \%$ of patients from $82 \%$ of the analyzed studies. Other symptoms including rhinorrhea, dizziness, and chills were less frequently reported. Additionally, in studies that reported C-reactive protein (CRP) measurements, a large majority of patients displayed an elevated CRP (60\%). Progression to acute respiratory distress syndrome (ARDS) was the most common complication of patients testing positive for COVID-19 (21\%). CT images displayed ground-glass opacification (GGO) patterns (80\%) as well as bilateral lung involvement (69\%). The most commonly used antiviral treatment modalities included, lopinavir (HIV protease inhibitor), arbidiol hydrochloride (influenza fusion inhibitor), and oseltamivir (neuraminidase inhibitor).

Conclusions: Development of ARDS may play a role in estimating disease progression and mortality risk. Early detection of elevations in serum CRP, combined with a clinical COVID-19 symptom presentation may be used as a surrogate marker for the presence and severity of the disease. There is a paucity of data surrounding the efficacy of treatments. There is currently not a well-established gold standard therapy for the treatment of diagnosed COVID-19. Further prospective investigations are necessary.

Keywords: COVID-19, clinical characteristics, diagnosis, treatment, systematic review 


\section{INTRODUCTION}

Late in December 2019 and early in January 2020, reports of a very progressive pneumonia-like respiratory syndrome, starting in Wuhan, China, induced global health concerns (1). Soon after the onset of disease, it was found that the pathogen was a new member of the coronaviridae family, named SARS-COV-2 which is now called 2019-n-CoV (2). The respiratory syndrome caused by $2019-n-C o V$ is called COVID-19. COVID-19 is characterized by low-grade fever, cough, dyspnea, lymphopenia, and groundglass opacities on chest CT scan $(3,4)$. COVID-19 is a highly contagious disease, probably an aerosol born one, with human to human transmission capacity which has implicated many countries all around the world (5). In this review article, we systematically surveyed case reports and case series from many countries in the world to give a picture of the epidemiology, clinical presentations, laboratory changes, imaging findings, diagnostic criteria, treatments, outcomes, prognostic factors, and risk factors of COVID-19 in hospitalized patients.

\section{METHODS}

This review conforms to the "Preferred Reporting Items for Systematic Reviews and Meta-Analyses" (PRISMA) statement (6).

\section{Search Strategy}

We carried out systematic searches of the literature in the following bibliographical databases: PubMed/Medline, Embase, and Web of Science. Search criteria included case reports and case series articles published up to April 24, 2020, and there were no restrictions regarding publication language. We used Google Translate for eligible articles published in languages other than English. The search terms for our review were: COVID19 , severe acute respiratory syndrome coronavirus 2, novel coronavirus, SARS-CoV-2, nCoV disease, SARS2, COVID-19, 2019-nCoV, coronavirus disease-19, coronavirus disease 2019, and 2019 novel coronavirus.

\section{Study Selection}

Studies included in the review met the following criteria: prospective or retrospective descriptive case reports and case series of COVID-19 in the hospital setting which included diagnostic methods, clinical manifestations, laboratory features, treatment, and outcomes. Articles describing experimental approaches as well as reviews and publications without peerreview processes were excluded.

All potentially relevant articles were screened in two stages for eligibility. In the first stage, the titles and abstracts of potentially relevant articles were screened independently by two reviewers (YF, PJ). In the second stage of assessment, the full text of those abstracts which met the inclusion criteria was retrieved and independently reviewed by the same authors. Disagreements and technical uncertainties were discussed and resolved between review authors (AT, SH, MA, MJN).

\section{Data Extraction}

The extracted data included bibliographic data, patient demographics (e.g., age and gender), radiological and laboratory findings, treatment protocols, and medical consequences. Two authors (AT, SH) independently extracted the data from the selected studies. The data was jointly reconciled, and disagreements were discussed and resolved between review authors (YF, PJ, MA, MJN).

\section{QUALITY ASSESSMENT}

The critical appraisal checklist for case reports provided by the Joanna Briggs Institute (JBI) was used to perform a quality assessment of the studies (7).

\section{RESULTS}

As illustrated in Figure 1, our systematic search resulted in an initial number of 6,004 of potentially relevant articles, of which 1,033 were excluded by title and abstract evaluation. Applying the inclusion/exclusion criteria to the full-text documents, 80 articles were eligible for inclusion in the systematic review. 42 case reports and 38 case series from 19 countries were identified with a total of 417 unique cases of COVID-19 with a mean age of 48 years (Table 1). The included case reports were published because of the following reasons: they reported (1) new CT findings; (2) new clinical manifestations; (3) new laboratory findings, (4) new treatment outcomes; (5) atypical manifestations and some were the first one in a specific country. Based on the JBI tool, the included studies had a low risk of bias. RTPCR COVID-19 was present in 79 (95\%) articles as inclusion criteria. In addition to RT-PCR, a CT scan served as a diagnostic tool in $16(19 \%)$ of papers. Reported comorbidities included hypertension, diabetes, cardiovascular disease, and pulmonary disease. Hypertension was investigated the most, studied in $22 / 83(26.5 \%)$ of papers. Of the 16 COVID-19 positive patients found in the studies investigating hypertension, 44 patients were hypertensive (19\%) (Table 2). Lymphopenia was reported in 24 studies which identified 83/185 (45\%) of COVID-19 positive patients. Additionally, in studies that reported C-reactive protein (CRP) measurements, a large majority of patients displayed an elevated CRP (60\%). CT images commonly displayed groundglass opacification (GGO) patterns $(82 \%)$ as well as bilateral lung involvement (66\%). Progression to acute respiratory distress syndrome (ARDS) was the most common complication of patients testing positive for COVID-19. We found 11/83 (13.2\%) reports on Acute Respiratory Distress Syndrome (ARDS), 18 of $86(21 \%)$ investigated cases had ARDS. Mortality outcomes were difficult to assess; only 10 studies showed mortality data in which 17/108 (16\%) COVID-19 patients died. A wide range of therapeutic modalities was tried across studies, with antiviral treatments being the most used.

Common antiviral treatment modalities included lopinavir (HIV protease inhibitor), arbidiol hydrochloride (influenza fusion inhibitor), and oseltamivir (neuraminidase inhibitor). In Table 3 we summarize all of the drugs used. 


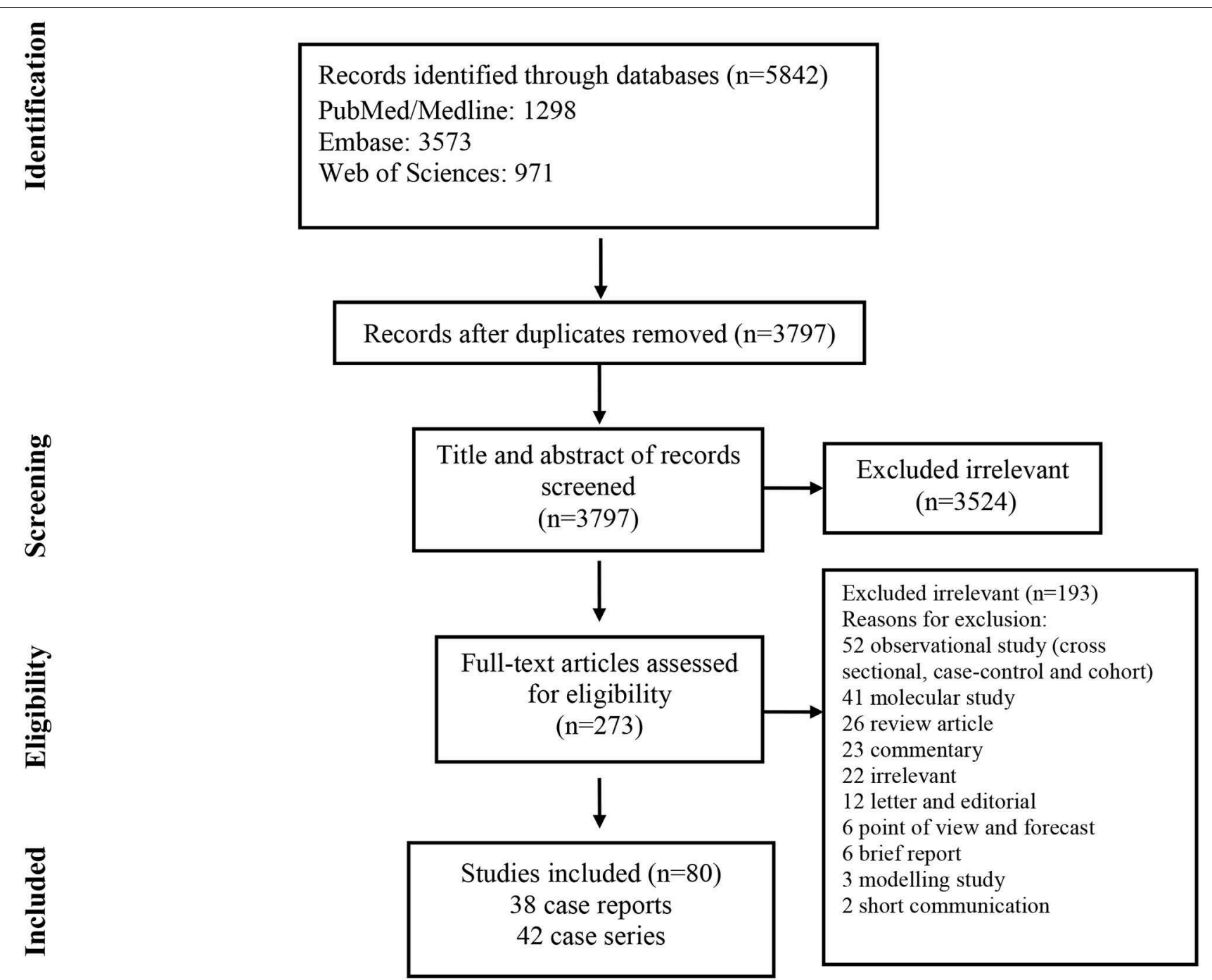

FIGURE 1 | Flow chart of study selection for inclusion in the systematic review.

\section{DISCUSSION}

The 2019 novel coronavirus has been declared a public health emergency worldwide. The World Health Organization (WHO) declared COVID-19 a pandemic affecting 110 countries around the world with a continued global spread. The 2019-nCoV is likely to be transmitted by asymptomatic individuals (86). Asymptomatic transfer leads to lower prevalence estimates and higher transmission rates in the community. Until universal screening and vaccination become available, it is necessary to trace close contacts of those testing positive for COVID-19 and quarantining contacts to prevent asymptomatic transmission.

According to the articles we included, 2019-nCoV can only be transferred from person to person (87). Chen et al. suggested that they had no evidence of vertical transmission from mother to child (36). Any person infected with 2019-nCoV can develop a clinical course of Covid-19. However, it is reported to cause the most severe symptoms such as respiratory failure in older men with comorbidities (88). Children, teenagers, and younger people mostly showed a mild presentation of the disease (89).

Based on our reviewed articles, hypertension, diabetes, cardiovascular disease, and pulmonary disease were the most common morbidities among COVID-19 patients. This point was also mentioned in Alraddadi et al. study about MERS-CoV patients (90). They showed that individuals with comorbidities like diabetes, smoking, and cardiovascular disease were associated with a more severe clinical course (90). According to Yang et al., chronic diseases can debilitate the immune system and make pro-inflammatory conditions, leading to more severe infection and subsequently higher mortality rates (91).

According to the included studies, the most common clinical manifestations were fever, cough, dyspnea, and myalgia or fatigue. Less common clinical manifestations included nausea or vomiting, dizziness, rhinorrhea, and chills. Liu et al. reported 
TABLE 1 | Characteristics of the included studies.

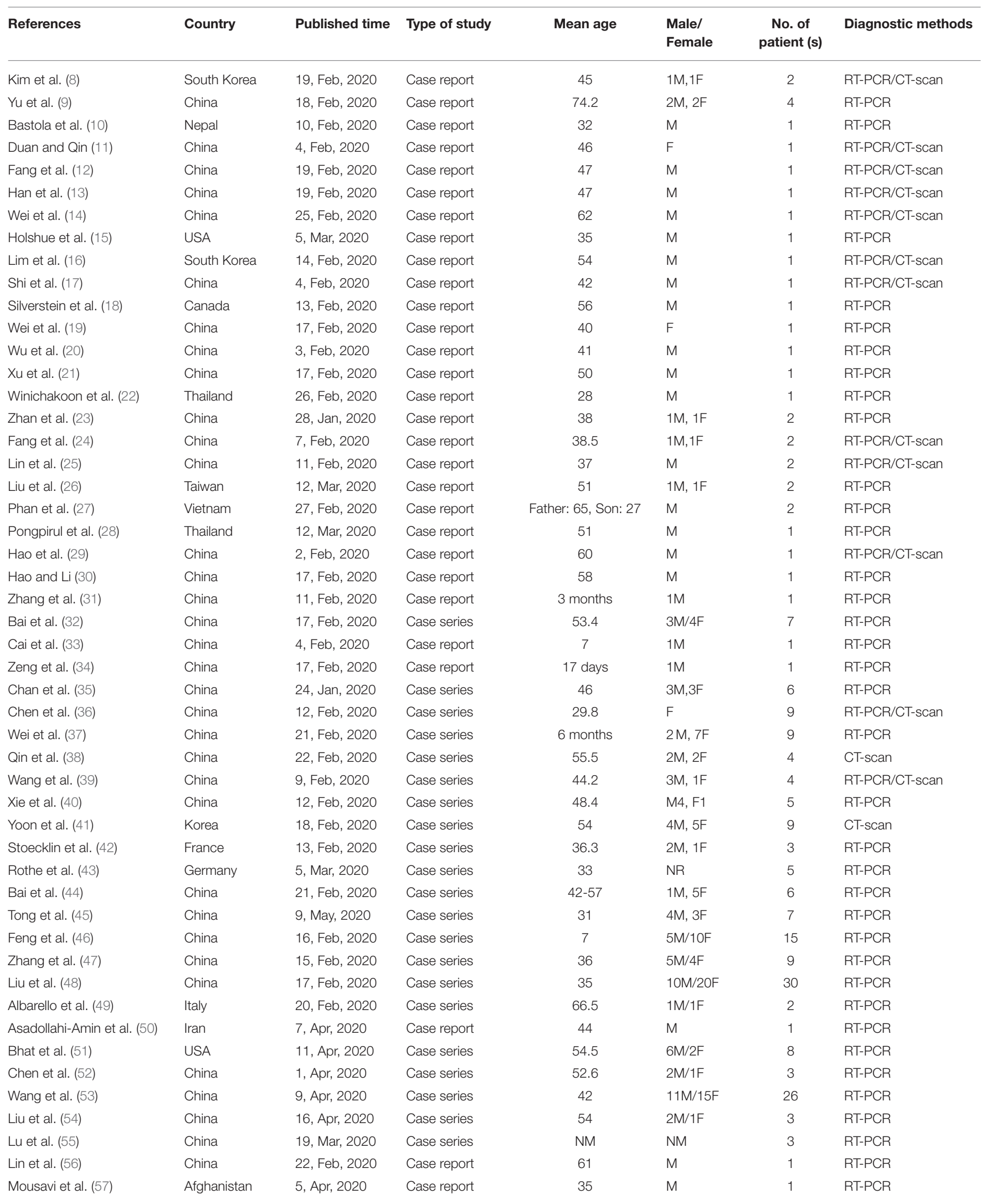


TABLE 1 | Continued

\begin{tabular}{|c|c|c|c|c|c|c|c|}
\hline References & Country & Published time & Type of study & Mean age & $\begin{array}{l}\text { Male/ } \\
\text { Female }\end{array}$ & $\begin{array}{c}\text { No. of } \\
\text { patient (s) }\end{array}$ & Diagnostic methods \\
\hline Hamer et al. (58) & Germany & 26, Mar, 2020 & Case report & 59 & M & 1 & RT-PCR \\
\hline Gupta et al. (59) & India & 10, Apr, 2020 & Case series & 40.3 & $14 \mathrm{M} / 7 \mathrm{~F}$ & 21 & RT-PCR \\
\hline Moreira et al. (60) & Brazil & 3, Apr, 2020 & Case report & 73 & M & 1 & RT-PCR \\
\hline Gao et al. (61) & China & 24, Mar, 2020 & Case series & 54.6 & $1 \mathrm{M} / 2 \mathrm{~F}$ & 3 & RT-PCR \\
\hline $\begin{array}{l}\text { Marchand-Senécal et al. } \\
(62)\end{array}$ & Canada & 9, Mar, 2020 & Case report & 56 & $\mathrm{M}$ & 1 & RT-PCR \\
\hline Lin et al. (25) & China & 11, Feb, 2020 & Case series & 37 & $2 \mathrm{M}$ & 2 & RT-PCR \\
\hline Makurumidze (63) & Zimbabwe & 2, Apr, 2020 & Case series & NM & $2 \mathrm{M} / 6 \mathrm{~F}$ & 8 & RT-PCR \\
\hline Li et al. (64) & China & 7, Apr, 2020 & Case series & 8 & $12 \mathrm{M} / 10 \mathrm{~F}$ & 22 & RT-PCR \\
\hline Li et al. (65) & China & 6, Apr, 2020 & Case report & 74 & $\mathrm{~F}$ & 1 & CT-Scan \\
\hline Li et al. (66) & China & 30, Mar, 2020 & Case series & 61 & $13 \mathrm{M} / 12 \mathrm{~F}$ & 25 & RT-PCR \\
\hline Cheng et al. (67) & Taiwan & 16, Apr, 2020 & Case report & 55 & $\mathrm{~F}$ & 1 & RT-PCR \\
\hline Edrada et al. (68) & Philippines & 14, Apr, 2020 & Case series & 41.5 & $1 \mathrm{M} / 1 \mathrm{~F}$ & 2 & RT-PCR \\
\hline Feng et al. (69) & China & 7, Apr, 2020 & Case report & 34 & M & 1 & CT-Scan \\
\hline Woznitza et al. (70) & UK & 2, Apr, 2020 & Case series & 78 & $1 \mathrm{M} / 2 \mathrm{~F}$ & 3 & RT-PCR \\
\hline Zeng et al. (71) & China & 5, Apr, 2020 & Case report & 63 & M & 1 & RT-PCR \\
\hline Zhang et al. (72) & China & 18, Mar, 2020 & Case report & 64 & M & 1 & RT-PCR \\
\hline Zhou et al. (73) & China & 3, Apr, 2020 & Case series & NM & $1 \mathrm{M} / 3 \mathrm{~F}$ & 4 & RT-PCR \\
\hline Torkian et al. (74) & Iran & 27, Mar, 2020 & Case series & 46 & $2 \mathrm{M} / 1 \mathrm{~F}$ & 3 & RT-PCR \\
\hline Tan et al. (75) & China & 3, Apr, 2020 & Case series & 7 & $3 \mathrm{M} / 7 \mathrm{~F}$ & 10 & RT-PCR \\
\hline Hase et al. (76) & Japan & 2, Apr, 2020 & Case report & 35 & $\mathrm{~F}$ & 1 & RT-PCR \\
\hline Huang et al. (77) & Taiwan & 19, Feb, 2020 & Case series & 73.7 & $2 \mathrm{~F}$ & 2 & RT-PCR \\
\hline Hu et al. (78) & China & 4, Mar, 2020 & Case series & 32.5 & $8 \mathrm{M} / 16 \mathrm{~F}$ & 24 & RT-PCR \\
\hline Hu et al. (78) & Italy & 27, Mar, 2020 & Case report & 53 & $\mathrm{~F}$ & 1 & RT-PCR \\
\hline Kim et al. (79) & South Korea & 6, Apr, 2020 & Case series & 40 & $15 \mathrm{M} / 13 \mathrm{~F}$ & 28 & RT-PCR \\
\hline Kim et al. (80) & South Korea & 3, Feb, 2020 & Case report & 35 & $\mathrm{~F}$ & 1 & RT-PCR \\
\hline Kong et al. (81) & South Korea & 14, Feb, 2020 & Case series & 42.6 & $15 \mathrm{M} / 13 \mathrm{~F}$ & 28 & RT-PCR \\
\hline Lee et al. (82) & Taiwan & 10, Mar, 2020 & Case report & 46 & $\mathrm{~F}$ & 1 & RT-PCR \\
\hline Lescure et al. (83) & France & 27, Mar, 2020 & Case series & 47 & $3 \mathrm{M} / 2 \mathrm{~F}$ & 5 & RT-PCR \\
\hline Wissenberg et al. (84) & Denmark & 3, Apr, 2020 & Case report & 50 & M & 1 & RT-PCR \\
\hline Li et al. (85) & China & 1, Mar, 2020 & Case series & 55 & $2 \mathrm{M} / 1 \mathrm{~F}$ & 3 & RT-PCR \\
\hline
\end{tabular}

that infants had mild clinical manifestations and a better prognosis. Furthermore, some asymptomatic cases were seen among children.

The most common abnormal laboratory changes were lymphopenia, high concentrations of $\mathrm{C}$-reactive protein, and elevated levels of aspartate aminotransferase; however, we do not know the exact pathogenesis and the reason for these alterations. Laboratory abnormalities may indicate the severity of disease and developing complications. According to Huang et al., most patients with secondary infection had a procalcitonin level $>0.5 \mathrm{ng} / \mathrm{Ml}$ and ICU patients had higher levels of prothrombin time and D-dimer (92). Also, Liu et al. mentioned using hypoalbuminemia, lymphopenia, high concentrations of CRP, and elevated $\mathrm{LDH}$ to predict the severity of acute lung injury (3). Higher levels of angiotensin II are also proposed to be related to acute lung injury (3). Meanwhile, nonsurvivors are suggested to have higher D-dimer and FDP levels, longer PT and aPTT, and lower fibrinogen and antithrombin levels (93).
CT scan as a diagnostic tool can be used to evaluate the severity of pulmonary involvement and monitor clinical progression. CT scan has good sensitivity and can be used to establish COVID-19 diagnosis in patients who are highly suspicious based on epidemiologic history and clinical manifestations but have negative PCR-based test results $(12,94)$. It is important to highlight that the CT scan can be normal during initial days, and a normal CT scan in a suspected case would never definitely rule out the diagnosis of COVID-19 (95). Moreover, the CT scan is dynamic in patients with COVID-19 and changes rapidly $(13,17,19)$. The earliest abnormal finding in the CT scan is the appearance of ground-glass opacities in peripheral and sub-pleural areas (96). As the disease progresses, the GGO's will expand and distribute more, most commonly to the right lower lung lobes. Later findings include consolidations, paving patterns, thickening of lobar fissures, and adjacent pleura. Pleural effusion, hilar lymphadenopathies, and mediastinal lymphadenopathies are not common findings and have only been reported scarcely (40). Lung pathology can progress to a 
TABLE 2 | Summary of the case report and case series findings.

\begin{tabular}{|c|c|c|c|c|}
\hline & Variables & $\begin{array}{l}\text { Number } \\
\text { of studies }\end{array}$ & $n / N^{*}$ & $\%$ \\
\hline \multirow[t]{4}{*}{ Comorbidities } & Hypertension & 22 & $44 / 228$ & 19 \\
\hline & $\begin{array}{l}\text { Cardiovascular } \\
\text { disease }\end{array}$ & 6 & $11 / 137$ & 8 \\
\hline & Diabetes & 17 & $27 / 241$ & 11 \\
\hline & Pulmonary disease & 8 & 13/107 & 12 \\
\hline \multirow[t]{12}{*}{ Clinical manifestations } & Fever & 68 & $248 / 401$ & 62 \\
\hline & Cough & 39 & $195 / 389$ & 50 \\
\hline & Dyspnea & 30 & $78 / 279$ & 28 \\
\hline & Myalgia/fatigue & 38 & $106 / 343$ & 31 \\
\hline & $\begin{array}{l}\text { Sputum } \\
\text { production }\end{array}$ & 14 & $49 / 197$ & 25 \\
\hline & Sore throat & 20 & $48 / 164$ & 29 \\
\hline & Headache & 11 & $37 / 149$ & 25 \\
\hline & Diarrhea & 14 & $21 / 94$ & 22 \\
\hline & Nausea/vomiting & 8 & $17 / 84$ & 20 \\
\hline & Dizziness & 5 & $5 / 35$ & 14 \\
\hline & Rhinorrhea & 13 & $22 / 196$ & 11 \\
\hline & Chills & 4 & $4 / 13$ & 31 \\
\hline \multirow[t]{10}{*}{ Laboratory findings } & Lymphopenia & 24 & $83 / 185$ & 45 \\
\hline & Leukopenia & 17 & $38 / 150$ & 25 \\
\hline & Thrombocytopenia & 8 & $26 / 69$ & 38 \\
\hline & High CRP & 18 & $118 / 197$ & 60 \\
\hline & High LDH & 14 & $34 / 77$ & 44 \\
\hline & High ESR & 10 & $17 / 42$ & 40 \\
\hline & High AST & 11 & $23 / 48$ & 48 \\
\hline & High ALT & 13 & $22 / 77$ & 28.5 \\
\hline & $\begin{array}{l}\text { High creatinine } \\
\text { kinase }\end{array}$ & 8 & $9 / 44$ & 20 \\
\hline & High creatinine & 4 & $6 / 32$ & 19 \\
\hline \multirow[t]{4}{*}{ CT } & $\begin{array}{l}\text { Both of GGO and } \\
\text { Consolidation }\end{array}$ & 16 & $32 / 59$ & 54 \\
\hline & $\begin{array}{l}\text { GGO without } \\
\text { consolidation }\end{array}$ & 20 & $48 / 60$ & 80 \\
\hline & Unilateral & 11 & $35 / 87$ & 40 \\
\hline & Bi lateral & 23 & $76 / 110$ & 69 \\
\hline \multirow[t]{2}{*}{ Complications } & ARDS & 11 & $18 / 86$ & 21 \\
\hline & Hospitalization & 30 & $77 / 83$ & 93 \\
\hline \multirow[t]{2}{*}{ Outcomes } & Discharged & 23 & $137 / 205$ & 67 \\
\hline & Death & 10 & $17 / 108$ & 16 \\
\hline
\end{tabular}

${ }^{*} n$, number of patients with any variables; $N$, the total number of patients with COVID-19.

"white lung" with low functional capacity or heal with some fibrotic remnants (40). Dynamic changes in the lungs seen on CT imaging will continue even after the patient's discharge (96). CT scan findings have prognostic value in some patients, as Shi et al. have reported, deterioration on follow-up CT scan, old age, male sex, and underlying comorbidities are associated with poor prognosis.
TABLE 3 | Treatment agents used in the included studies.

\begin{tabular}{|c|c|c|c|c|c|}
\hline & Treatment & Agents & $\begin{array}{l}\text { Number } \\
\text { of studies }\end{array}$ & $n / N^{*}$ & $\%$ \\
\hline \multirow{25}{*}{$\begin{array}{l}\text { Pharmacologic } \\
\text { treatment }\end{array}$} & \multirow{8}{*}{$\begin{array}{l}\text { Antiviral } \\
\text { drugs }\end{array}$} & Lopinavir & 6 & $9 / 9$ & 100 \\
\hline & & $\begin{array}{l}\text { Arbidol } \\
\text { hydrochloride }\end{array}$ & 2 & $6 / 6$ & 100 \\
\hline & & Oseltamivir & 5 & $1 / 1$ & 100 \\
\hline & & Veletonavir & 1 & $1 / 1$ & 100 \\
\hline & & Remdesivir & 1 & $1 / 1$ & 100 \\
\hline & & Ribavirin & 1 & $1 / 1$ & 100 \\
\hline & & Ritonavir & 1 & $1 / 1$ & 100 \\
\hline & & Gancyclovir & 1 & $1 / 1$ & 100 \\
\hline & \multirow{8}{*}{$\begin{array}{l}\text { Antibacterial } \\
\text { drugs }\end{array}$} & Moxifloxacin & 4 & $5 / 5$ & 100 \\
\hline & & Vancomycin & 1 & $1 / 1$ & 100 \\
\hline & & Cefepime & 1 & $1 / 1$ & 100 \\
\hline & & Meropenem & 2 & $2 / 2$ & 100 \\
\hline & & $\begin{array}{l}\text { Piperacillin } \\
\text { tazobactam }\end{array}$ & 2 & $2 / 2$ & 100 \\
\hline & & Sefoselis & 1 & $1 / 1$ & 100 \\
\hline & & Linezolid & 1 & $1 / 1$ & 100 \\
\hline & & Levofloxacin & 1 & $1 / 2$ & 50 \\
\hline & \multirow[t]{9}{*}{ Others } & Methylprednisolone & ne 5 & $6 / 6$ & 100 \\
\hline & & $\begin{array}{l}\text { Ambroxol } \\
\text { Hydrochloride }\end{array}$ & 1 & $1 / 1$ & 100 \\
\hline & & Acetaminophen & 2 & $2 / 2$ & 100 \\
\hline & & Ibuprofen & 2 & $2 / 2$ & 100 \\
\hline & & $\begin{array}{l}\text { Intravenous } \\
\text { Immunoglobulin }\end{array}$ & 3 & $4 / 7$ & 57 \\
\hline & & Guaifenesin & 1 & $1 / 1$ & 100 \\
\hline & & Ondansetron & 1 & $1 / 1$ & 100 \\
\hline & & $\begin{array}{l}\text { Interferon } \\
\text { alpha-2b }\end{array}$ & 2 & $2 / 2$ & 100 \\
\hline & & $\begin{array}{l}\text { Herbal } \\
\text { patent } \\
\text { medicine }\end{array}$ & 2 & $3 / 3$ & 100 \\
\hline $\begin{array}{l}\text { Non- } \\
\text { pharmacologic } \\
\text { treatment }\end{array}$ & $\begin{array}{l}\text { Oxygen } \\
\text { therapy }\end{array}$ & $\begin{array}{l}\text { Non- } \\
\text { invasive }\end{array}$ & 6 & $10 / 10$ & 100 \\
\hline
\end{tabular}

ARDS was the most common complication among the confirmed COVID-19 patients; the development of ARDS increased the risk of patient mortality (97). Huang et al. reported that the median time from onset of symptoms to the development of ARDS was 9 days (92). Other complications were acute cardiac injury, acute kidney injury, secondary infection, and shock that leads to multiple organ failure $(98,99)$. ICU patients in comparison to non-ICU patients were also more likely to have complications (100). The mortality rate was higher in critically ill patients as well as in older patients with comorbidities and ARDS. Yang et al. reported that the median duration from ICU admission to death was 7 days (97). The window between the presentation to the time of ICU 
admission and/or development of ARDS is an optimal time for medical intervention.

Also, the results of the current study are in comparison with the recent large patient cohort studies in the aspect of comorbidities, clinical manifestations, laboratory, and radiological findings, however, there are some differences $(101,102)$. In a study by Richardson et al., a more detailed analysis of the patient's vital signs, ICU interventions, outcome characteristics, and risk factors were reported (101). According to their study, among the patients who were discharged or had died during hospitalization, $14.2 \%$ were treated in the ICU, $12.2 \%$ received invasive mechanical ventilation, $3.2 \%$ were treated with kidney replacement therapy, and $21 \%$ died. Moreover, Grasselli et al. indicated that Older patients (age $\geq 64$ years) had higher mortality than younger patients (age $\leq 63$ years) (36\%vs 15\%) (102).

There are many challenges in COVID-19 therapeutic strategies. There is currently no cure for COVID-19. However, pharmacologic and non-pharmacologic symptom management and supportive care measures should be given to all patients with symptomatic COVID-19. Other various therapeutic strategies have been trialed in patients with COVID-19 to slow disease progression. There is a paucity of data surrounding the efficacy of treatments. Of the case controls and case series we included, antiviral agents including HIV protease inhibitors (lopinavir and ritonavir) as well as anti-influenza compounds (oseltamivir and arbidol) were used as treatment regimens. Unfortunately, we didn't have enough information about the efficacy of each regimen; however, according to some studies, anti-HIV based medications could have benefits in more rapid improvement of clinical manifestations and decrease in viral load $(13,16,19)$.

A limitation of this review relates to the potential risk of bias. Bias occurs in the case reports/series studies because their results are not representative and do not represent the truth. A further limitation is that the conclusions are limited due to the case reports and case series. We did not include observational studies and randomized controlled trial (RCT)/quasi-randomized studies, because another study being conducted by the authors. Furthermore, the focus of the reviewed case reports and case series was mainly on the clinical description of the patients with COVID-19, but detailed information on the treatment outcomes and medical consequences were rarely provided. Also, the case number included in this systematic review is low compared with the currently published patient

\section{REFERENCES}

1. Zhu N, Zhang D, Wang W, Li X, Yang B, Song J, et al. A novel coronavirus from patients with pneumonia in China, 2019. N Engl J Med. (2020) 382:72733. doi: 10.1056/NEJMoa2001017

2. Lu R, Zhao X, Li J, Niu P, Yang B, Wu H, et al. Genomic characterisation and epidemiology of 2019 novel coronavirus: implications for virus origins and receptor binding. Lancet. (2020) 395:565-74. doi: 10.1016/S0140-6736(20)30251-8

3. Liu Y, Yang Y, Zhang C, Huang F, Wang F, Yuan J, et al. Clinical and biochemical indexes from 2019-nCoV infected patients linked cohort, and this may lead to the declining clinical significance of this manuscript. Finally, our results are limited to younger adults who had been hospitalized during the $4-5$ first months of the COVID-19 pandemic.

In conclusion, we discussed the clinical symptoms, laboratory abnormalities, common comorbidities, imaging modalities, and potential therapeutic options in COVID-19. We indicated that the most common symptoms were fever, cough, and dyspnea, but some young infected cases had no signs or symptoms. ARDS was the most common reported complication and was associated with poor prognosis. In the wake of the COVID-19 pandemic, countries are scrambling to produce enough RT-PCR diagnostic tests. Diagnostic information from other surrogate markers would be valuable if markers proved to be sensitive and specific. Namely, we learned that laboratory data like CRP may not only be related to the severity of the disease, but it may be predictive of disease outcomes. Further studies are needed to relate quantified elevations in CRP to disease severity. Due to the high sensitivity of the CT scan, it is considered as a good diagnostic tool. However, it should be kept in mind that a normal CT scan will never rule out the diagnosis of COVID-19 in a highly suspicious case based on history and clinical findings. Lastly, there are different therapeutic strategies for COVID19 patients, but we don't have enough data for their efficacy. Additional investigations including randomized controlled trials will be necessary to further our understanding of the treatment of COVID-19.

\section{DATA AVAILABILITY STATEMENT}

All datasets presented in this study are included in the article/ supplementary material.

\section{AUTHOR CONTRIBUTIONS}

MN and MM designed the study and revised the manuscript. $\mathrm{MN}, \mathrm{AT}, \mathrm{MA}, \mathrm{YF}, \mathrm{PJ}, \mathrm{SH}$, and TC performed the search, data extraction, statistical analysis, and wrote the first draft of the manuscript.

\section{FUNDING}

This study was financially supported by Research Department of the School of Medicine, Shahid Beheshti University of Medical Sciences, Tehran, Iran (Grant number: 22960). 
7. Institute JB. The Joanna Briggs Institute Critical Appraisal Tools for Use in JBI Systematic Review: Checklists for Case Reports (2019).

8. Kim JY, Ko JH, Kim Y, Kim YJ, Kim JM, Chung YS, et al. Viral load kinetics of SARS-CoV-2 infection in first two patients in Korea. J Kor Med Sci. (2019) 35:e86. doi: $10.3346 / \mathrm{jkms.2020.35.e86}$

9. Yu P, Zhu J, Zhang Z, Han Y, Huang L. A familial cluster of infection associated with the 2019 novel coronavirus indicating potential personto-person transmission during the incubation period. J Infect Dis. (2020) jiaa077. doi: 10.1093/infdis/jiaa077. [Epub ahead of print].

10. Bastola A, Sah R, Rodriguez-Morales AJ, Lal BK, Jha R, Ojha HC, et al. The first 2019 novel coronavirus case in Nepal. Lancet Infect Dis. (2020) 20:279-80. doi: 10.1016/S1473-3099(20)30067-0

11. Duan YN, Qin J. Pre-and posttreatment chest CT findings: 2019 novel coronavirus (2019-nCoV) pneumonia. Radiology. (2020) 295:18. doi: 10.1148/radiol.2020200323

12. Fang X, Zhao M, Li S, Yang L, Wu B. Changes of CT findings in a 2019 novel Coronavirus (2019-nCoV) pneumonia patient. QJM. (2020) 113:2712. doi: 10.1093/qjimed/hcaa038

13. Han W, Quan B, Guo Y, Zhang J, Lu Y, Feng G, et al. The course of clinical diagnosis and treatment of a case infected with coronavirus disease 2019. J Med Virol. (2020). 92:461-3. doi: 10.1002/jmv.25711

14. Wei H, Yin H, Huang M, Guo Z. The 2019 novel cornoavirus pneumonia with onset of oculomotor nerve palsy: a case study. J Neurol. (2020) 267:1550-53. doi: 10.1007/s00415-020-09773-9

15. Holshue ML, DeBolt C, Lindquist S, Lofy KH, Wiesman J, Bruce H, et al. First case of 2019 novel coronavirus in the United States. N Engl J Med. (2020) 382:929-36. doi: 10.1056/NEJMoa2001191

16. Lim J, Jeon S, Shin HY, Kim MJ, Seong YM, Lee WJ, et al. Case of the index patient who caused tertiary transmission of Coronavirus disease 2019 in Korea: the application of lopinavir/ritonavir for the treatment of COVID19 pneumonia monitored by quantitative RT-PCR. J Kor Med Sci. (2020) 35:e79. doi: 10.3346/jkms.2020.35.e89

17. Shi H, Han X, Zheng C. Evolution of CT manifestations in a patient recovered from 2019 novel coronavirus (2019-nCoV) pneumonia in Wuhan, China. Radiology. (2020) 295:20. doi: 10.1148/radiol.2020200269

18. Silverstein WK, Stroud L, Cleghorn GE, Leis JA. First imported case of 2019 novel coronavirus in Canada, presenting as mild pneumonia. Lancet. (2020) 395:734. doi: 10.1016/S0140-6736(20)30370-6

19. Wei J, Xu H, Xiong J, Shen Q, Fan B, Ye C, et al. 2019 novel Coronavirus (COVID-19) pneumonia: serial computed tomography findings. Kor $J$ Radiol. (2020) 21:501-4. doi: 10.3348/kjr.2020.0112

20. Wu F, Zhao S, Yu B, Chen Y-M, Wang W, Song ZG, et al. A new coronavirus associated with human respiratory disease in China. Nature. (2020) 579:2659. doi: $10.1038 / \mathrm{s} 41586-020-2008-3$

21. Xu Z, Shi L, Wang Y, Zhang J, Huang L, Zhang C, et al. Pathological findings of COVID-19 associated with acute respiratory distress syndrome. Lancet Respir Medicine. (2020) 8:420-2. doi: 10.1016/S2213-2600(20)30076-X

22. Winichakoon $\mathrm{P}$, Chaiwarith R, Liwsrisakun C, Salee P, Goonna A, Limsukon A, et al. Negative nasopharyngeal and oropharyngeal swab does not rule out COVID-19. J Clin Microbiol. (2020) 58:e0029720. doi: 10.1128/JCM.00297-20

23. Zhang Z, Li X, Zhang W, Shi ZL, Zheng Z, Wang T. Clinical features and treatment of 2019-nCov pneumonia patients in Wuhan: report of a couple cases. Virol Sin. (2020). doi: 10.1007/s12250-020-00203-8. [Epub ahead of print].

24. Fang $\mathrm{Y}$, Zhang $\mathrm{H}, \mathrm{Xu} \mathrm{Y}, \mathrm{Xie}$ J, Pang P, Ji W. CT manifestations of two cases of 2019 novel coronavirus (2019-nCoV) pneumonia. Radiology. (2020) 295:200280. doi: 10.1148/radiol.2020200280

25. Lin X, Gong Z, Xiao Z, Xiong J, Fan B, Liu J. Novel coronavirus pneumonia outbreak in 2019: computed tomographic findings in two cases. Kor J Radiol. (2020) 21:365-8. doi: 10.3348/kjr.2020.0078

26. Liu YC, Liao CH, Chang CF, Chou CC, Lin YR. A Locally transmitted case of SARS-CoV-2 infection in Taiwan. N Engl J Med. (2020) 382:107072. doi: 10.1056/NEJMc2001573

27. Phan LT, Nguyen TV, Luong QC, Nguyen TV, Nguyen HT, Le HQ, et al. Importation and human-to-human transmission of a novel coronavirus in Vietnam. N Engl J Med. (2020) 382:872-4. doi: 10.1056/NEJMc2001272
28. Pongpirul WA, Pongpirul K, Ratnarathon AC, Prasithsirikul W. Journey of a Thai Taxi driver and novel coronavirus. N Engl J Med. (2020) 382:10678. doi: 10.1056/NEJMc2001621

29. Hao W, Li M, Huang X. First Atypical case of 2019 novel coronavirus in Yan'an, China. Clin Microbiol Infect. (2020). doi: 10.1016/j.cmi.2020.02.011. [Epub ahead of print].

30. Hao W, Li M. Clinical features of atypical 2019 novel coronavirus pneumonia with an initially negative RT-PCR assay. $J$ Infect. (2020). doi: 10.1016/j.jinf.2020.02.008. [Epub ahead of print].

31. Zhang YH, Lin DJ, Xiao MF, Wang JC, Wei Y, Lei ZX, et al. 2019-novel coronavirus infection in a three-month-old baby. Zhonghua Za Zhi. (2020) 58:E006. doi: 10.3760/cma.j.issn.0578-1310.2020.0006

32. Bai SL, Wang JY, Zhou YQ, Yu DS, Gao XM, Li LL, et al. Analysis of the first cluster of cases in a family of novel coronavirus pneumonia in Gansu Province. Zhonghua Fang Xue Za Zhi. (2020) 54:E005. doi: 10.3760/cma.j.issn.0253-9624.2020.0005

33. Cai JH, Wang XS, Ge YL, Xia AM, Chang HL, Tian H, et al. First case of 2019 novel coronavirus infection in children in Shanghai. Zhonghua Za Zhi. (2020) 58:E002. doi: 10.3760/cma.j.issn.0578-1310.2020.0002

34. Zeng LK, Tao XW, Yuan WH, Wang J, Liu X, Liu ZS. First case of neonate infected with novel coronavirus pneumonia in China. Zhonghua Za Zhi. (2020) 58:E009. doi: 10.3760/cma.j.issn.0578-1310.2020.0009

35. Chan JF, Yuan S, Kok KH, To KK, Chu H, Yang J, et al. A familial cluster of pneumonia associated with the 2019 novel coronavirus indicating personto-person transmission: a study of a family cluster. Lancet. (2020) 395:51423. doi: 10.1016/S0140-6736(20)30154-9

36. Chen H, Guo J, Wang C, Luo F, Yu X, Zhang W, et al. Clinical characteristics and intrauterine vertical transmission potential of COVID-19 infection in nine pregnant women: a retrospective review of medical records. Lancet. (2020) 395:809-15. doi: 10.1016/S0140-6736(20)30360-3

37. Wei M, Yuan J, Liu Y, Fu T, Yu X, Zhang ZJ. Novel coronavirus infection in hospitalized infants under 1 year of age in China. JAMA. (2020) 323:131314. doi: 10.1001/jama.2020.2131

38. Qin C, Liu F, Yen TC, Lan X. 18 F-FDG PET/CT findings of COVID-19: a series of four highly suspected cases. Eur J Nucl Med Mol Imaging. (2020) 47:1281-6. doi: 10.1007/s00259-020-04734-w

39. Wang Z, Chen X, Lu Y, Chen F, Zhang W. Clinical characteristics and therapeutic procedure for four cases with 2019 novel coronavirus pneumonia receiving combined Chinese and Western medicine treatment. BioScience Trends. (2020) 14:64-8. doi: 10.5582/bst.2020.01030

40. Xie X, Zhong Z, Zhao W, Zheng C, Wang F, Liu J. Chest CT for typical 2019-nCoV pneumonia: relationship to negative RT-PCR testing. Radiology. (2020) 200343. doi: 10.1148/radiol.2020200343. [Epub ahead of print].

41. Yoon SH, Lee KH, Kim JY, Lee YK, Ko H, Kim KH., et al. Chest radiographic and CT findings of the 2019 Novel Coronavirus Disease (COVID-19): analysis of nine patients treated in Korea. Kor J Radiol. (2020) 21:494500. doi: 10.3348/kjr.2020.0132

42. Stoecklin BS, Rolland P, Silue Y, Mailles A, Campese C, Simondon A, et al. First cases of coronavirus disease 2019 (COVID-19) in France: surveillance, investigations and control measures, January 2020. Eurosurveillance. (2020) 25:2000094. doi: 10.2807/1560-7917.ES.2020.25.6.2000094

43. Rothe C, Schunk M, Sothmann P, Bretzel G, Froeschl G, Wallrauch C, et al. Transmission of 2019-nCoV infection from an asymptomatic contact in Germany. N Engl J Med. (2020) 382:970-1. doi: 10.1056/NEJMc2001468

44. Bai Y, Yao L, Wei T, Tian F, Jin DY, Chen L, et al. Presumed asymptomatic carrier transmission of COVID-19. JAMA. (2020) 323:14067. doi: 10.1001/jama.2020.2565

45. Tong ZD, Tang A, Li KF, Li P, Wang HL, Yi JP, et al. Potential Presymptomatic Transmission of SARS-CoV-2, Zhejiang Province, China, 2020. Emerg Infect Dis. (2020) 26:1052-4. doi: 10.3201/eid2605.200198

46. Feng K, Yun YX, Wang XF, Yang GD, Zheng YJ, Lin CM, et al. Analysis of CT features of 15 children with 2019 novel coronavirus infection. Zhonghua Za Zhi. (2020) 58:E007. doi: 10.3760/cma.j.issn.0578-1310.2020.0007

47. Zhang MQ, Wang XH, Chen YL, Zhao KL, Cai YQ, An CL, et al. Clinical features of 2019 novel coronavirus pneumonia in the early stage from a fever clinic in Beijing. Zhonghua Jie He He Hu Xi Za Zhi. (2020) 43:E013. doi: 10.3760/cma.j.issn.1001-0939.2020.0013 
48. Liu M, He P, Liu HG, Wang WJ, Li FJ, Chen S, et al. Clinical characteristics of 30 medical workers infected with new coronavirus pneumonia. Zhonghua Jie He He Hu Xi Za Zhi. (2020) 43:E016. doi: 10.3760/cma.j.issn.1001-0939.2020.0016

49. Albarello F, Pianura E, Di Stefano F, Cristofaro M, Petrone A, Marchioni L, et al. 2019-novel Coronavirus severe adult respiratory distress syndrome in two cases in Italy: an uncommon radiological presentation. Int J Infect Dis. (2020) 93:192-7. doi: 10.1016/j.ijid.2020.02.043

50. Asadollahi-Amin A, Hasibi M, Ghadimi F, Rezaei H, SeyedAlinaghi S. Lung involvement found on chest ct scan in a pre-symptomatic person with SARS-CoV-2 infection: a case report. Trop Med Infect Dis. (2020) 5:56. doi: 10.3390/tropicalmed5020056

51. Bhat R, Hamid A, Kunin JR, Saboo SS, Batra K, Baruah D, et al. Chest imaging in patients hospitalized with COVID-19 infection-a case series. Curr Problems Diagn Radiol. (2020). doi: 10.1067/j.cpradiol.2020.04.001. [Epub ahead of print].

52. Chen X, Liu S, Zhang C, Pu G, Sun J, Shen J, et al. Dynamic chest ct evaluation in three cases of 2019 novel coronavirus pneumonia. Arch Iranian Med. (2020) 23:277-80. doi: 10.34172/aim.2020.11

53. Wang L, Duan Y, Zhang W, Liang J, Xu J, Zhang Y, et al. Epidemiologic and Clinical characteristics of 26 cases of COVID-19 arising from patient-to-patient transmission in Liaocheng, China. Clin Epidemiol. (2020) 12:387. doi: 10.2147/CLEP.S249903

54. Liu C, Wu C, Zheng X, Zeng F, Liu J, Wang P, et al. Clinical features and multidisciplinary treatment outcome of COVID-19 pneumonia: a report of three cases. J Formosan Med Assoc. (2020). doi: 10.1016/j.jfma.2020.04.008. [Epub ahead of print].

55. Lu S, Lin J, Zhang Z, Xiao L, Jiang Z, Chen J, et al. Alert for non-respiratory symptoms of Coronavirus Disease 2019 (COVID-19) patients in epidemic period: a case report of familial cluster with three asymptomatic COVID19 patients. J Med Virol. (2020). doi: 10.1002/jmv.25776. [Epub ahead of print].

56. Lin C, Ding Y, Xie B, Sun Z, Li X, Chen Z, et al. Asymptomatic novel coronavirus pneumonia patient outside Wuhan: the value of CT images in the course of the disease. Clin Imaging. (2020) 63:79. doi: 10.1016/j.clinimag.2020.02.008

57. Mousavi SH, Shah J, Giang HTN, Al-Ahdal TMA, Zahid SU, Temory F, et al. The first COVID-19 case in Afghanistan acquired from Iran. Lancet Infect Dis. (2020). doi: 10.1016/S1473-3099(20)30231-0. [Epub ahead of print].

58. Hamer OW, Salzberger B, Gebauer J, Stroszczynski C, Pfeifer M. CT morphology of COVID-19: Case report and review of literature. Rofo. (2020). 192:386-92. doi: 10.1055/a-1142-4094

59. Gupta N, Agrawal S, Ish P, Mishra S, Gaind R, Usha G, et al. Clinical and epidemiologic profile of the initial COVID-19 patients at a tertiary care centre in India. Monaldi Arch Chest Dis. (2020) 90:193-6. doi: 10.4081/monaldi.2020.1294

60. Moreira BL, Brotto MPD, Marchiori E. Chest radiography and computed tomography findings from a Brazilian patient with COVID-19 pneumonia. Rev Socied Brasileira Med Trop. (2020) 53:e20200134. doi: 10.1590/0037-8682-0134-2020

61. Gao X, Yuan Z, Yang D, Li H, Zhang Y, Gao P, et al. A family cluster of severe acute respiratory syndrome coronavirus 2 infections. Eur J Clin Microbiol Infect Dis. (2020) 1:1-5. doi: 10.21203/rs.3.rs-16921/v1

62. Marchand-Senécal X, Kozak R, Mubareka S, Salt N, Gubbay JB, Eshaghi A, et al. Diagnosis and management of first case of COVID-19 in Canada: lessons applied from SARS. Clin Infect Dis. (2020). doi: 10.1093/cid/ciaa227. [Epub ahead of print].

63. Makurumidze R. Coronavirus-19 Disease (COVID-19): a case series of early suspects reported and the implications towards the response to the pandemic in Zimbabwe. J Microbiol Immunol Infect. (2020). doi: 10.1016/j.jmii.2020.04.002. [Epub ahead of print].

64. Li B, Shen J, Li L, Yu C. Radiographic and clinical features of children with 2019 novel coronavirus (COVID-19) pneumonia. Indian Pediatr. (2020). [Epub ahead of print].

65. Li RL, Chu SG, Luo Y, Huang ZH, Hao Y, Fan CH. Atypical presentation of SARS-CoV-2 infection: a case report. World J Clin Cases. (2020) 8:126570. doi: 10.12998/wjcc.v8.i7.1265
66. Li YK, Peng S, Li L-Q, Wang Q, Ping W, Zhang N, et al. Clinical and transmission characteristics of Covid-19-a retrospective study of 25 cases from a single thoracic surgery department. Curr Med Sci. (2020) 40:295300. doi: 10.1007/s11596-020-2176-2

67. Cheng SC, Chang YC, Fan Chiang YL, Chien YC, Cheng M, Yang CH, et al. First case of Coronavirus Disease 2019 (COVID-19) pneumonia in Taiwan. J Formosan Med Assoc. (2020) 119:747-51. doi: 10.1016/j.jfma.2020. 02.007

68. Edrada EM, Lopez EB, Villarama JB, Salva Villarama EP, Dagoc BF, Smith C, et al. First COVID-19 infections in the Philippines: a case report. Trop Med Health. (2020) 48:1-7. doi: 10.1186/s41182-020-00203-0

69. Feng H, Liu Y, Lv M, Zhong J. A case report of COVID-19 with false negative RT-PCR test: necessity of chest CT. Jap J Radiol. (2020) 38:12. doi: 10.1007/s11604-020-00967-9

70. Woznitza N, Nair A, Hare SS. COVID-19: a case series to support radiographer preliminary clinical evaluation. Radiography. (2020). doi: 10.1016/j.radi.2020.04.002. [Epub ahead of print].

71. Zeng JH, Liu YX, Yuan J, Wang FX, Wu WB, Li JX, et al. First case of COVID19 complicated with fulminant myocarditis: a case report and insights. Infection. (2020) 1:1-5. doi: 10.1007/s15010-020-01424-5

72. Zhang X, Song W, Liu X, Lyu L. CT image of novel coronavirus pneumonia: a case report. Jap J Radiol. (2020) 38:407-8. doi: 10.1007/s11604-020-00945-1

73. Zhou Y, Yang L, Han M, Huang M, Sun X, Zheng W, et al. Case report on early diagnosis of COVID-19. Disaster Med Public Health Prepared. (2020). doi: 10.1017/dmp.2020.66. [Epub ahead of print].

74. Torkian P, Ramezani N, Kiani P, Bax MR, Akhlaghpoor S. Common CT findings of novel Coronavirus Disease 2019 (COVID-19): a case series. Cureus. (2020) 12:e7434. doi: 10.7759/cureus.7434

75. Tan YP, Tan BY, Pan J, Wu J, Zeng SZ, Wei HY. Epidemiologic and clinical characteristics of 10 children with coronavirus disease 2019 in Changsha, China. J Clin Virol. (2020) 127:104353. doi: 10.1016/j.jcv.2020.104353

76. Hase R, Kurita T, Muranaka E, Sasazawa H, Mito H, Yano Y. A case of imported COVID-19 diagnosed by PCR-positive lower respiratory specimen but with PCR-negative throat swabs. Infect Dis. (2020) 52:4236. doi: 10.1080/23744235.2020.1744711

77. Huang WH, Teng LC, Yeh TK, Chen YJ, Lo WJ, Wu MJ, et al. 2019 novel coronavirus disease (COVID-19) in Taiwan: reports of two cases from Wuhan, China. J Microbiol Immunol Infect. (2020). doi: 10.1016/j.jmii.2020.02.009. [Epub ahead of print].

78. $\mathrm{Hu} \mathrm{Z}$, Song $\mathrm{C}$, $\mathrm{Xu} \mathrm{C}$, Jin $\mathrm{G}$, Chen $\mathrm{Y}, \mathrm{Xu} \mathrm{X}$, et al. Clinical characteristics of 24 asymptomatic infections with COVID-19 screened among close contacts in Nanjing, China. Sci China Life Sci. (2020) 63:706-11. doi: 10.2139/ssrn.3543598

79. Kim ES, Chin BS, Kang CK, Kim NJ, Kang YM, Choi JP, et al. Clinical course and outcomes of patients with severe acute respiratory syndrome coronavirus 2 infection: a preliminary report of the first 28 patients from the korean cohort study on COVID-19. J Kor Med Sci. (2020) 35:e142. doi: 10.3346/jkms.2020.35.e142

80. Kim JY, Choe PG, Oh Y, Oh KJ, Kim J, Park SJ, et al. The first case of 2019 novel coronavirus pneumonia imported into Korea from Wuhan, China: implication for infection prevention and control measures. J Kor Med Sci. (2020) 35:e61. doi: 10.3346/jkms.2020.35.e61

81. Kong I, Park Y, Woo Y, Lee J, Cha J, Choi J, et al. Early epidemiological and clinical characteristics of 28 cases of coronavirus disease in South Korea. Osong Public Health Res Perspect. (2020) 11:8-14. doi: 10.24171/j.phrp.2020. 11.1 .03

82. Lee NY, Li CW, Tsai HP, Chen PL, Syue LS, Li MC, et al. A case of COVID-19 and pneumonia returning from Macau in Taiwan: clinical course and anti-SARS-CoV-2 IgG dynamic. J Microbiol Immunol Infect. (2020). doi: 10.1016/j.jmii.2020.03.003. [Epub ahead of print].

83. Lescure FX, Bouadma L, Nguyen D, Parisey M, Wicky PH, Behillil S, et al. Clinical and virological data of the first cases of COVID-19 in Europe: a case series. Lancet Infect Dis. (2020). doi: 10.1016/S1473-3099(20)30200-0. [Epub ahead of print].

84. Wissenberg M, Andersen LPK, Pallisgaard JL, Lawson-Smith P. Fatal outcome of coronavirus disease 2019 in a previously healthy 50-year-old man. Ugeskrift Laeger. (2020) 182:V03200196. 
85. Li CX, Wu B, Luo F, Zhang N. Clinical study and CT findings of a familial cluster of pneumonia with Coronavirus Disease 2019 (COVID-19). Sichuan da Xue Xиe Bao. (2020) 51:155-8. doi: 10.12182/20200360107

86. Zou L, Ruan F, Huang M, Liang L, Huang H, Hong Z, et al. SARS-CoV-2 viral load in upper respiratory specimens of infected patients. $N$ Engl J Med. (2020) 382:1177-9. doi: 10.1056/NEJMc2001737

87. Li Q, Guan X, Wu P, Wang X, Zhou L, Tong Y, et al. Early transmission dynamics in Wuhan, China, of novel coronavirus-infected pneumonia. $N$ Engl J Med. (2020) 382:1199-207. doi: 10.1056/NEJMoa2001316

88. Chen N, Zhou M, Dong X, Qu J, Gong F, Han Y, et al. Epidemiological and clinical characteristics of 99 cases of 2019 novel coronavirus pneumonia in Wuhan, China: a descriptive study. Lancet. (2020) 395:50713. doi: 10.1016/S0140-6736(20)30211-7

89. Xu YH, Dong JH, An WM, Lv XY, Yin XP, Zhang JZ, et al. Clinical and computed tomographic imaging features of Novel Coronavirus Pneumonia caused by SARS-CoV-2. J Infect. (2020) 80:394-400. doi: 10.1016/j.jinf.2020.02.017

90. Alraddadi BM, Watson JT, Almarashi A, Abedi GR, Turkistani A, Sadran $\mathrm{M}$, et al. Risk factors for primary Middle East respiratory syndrome coronavirus illness in humans, Saudi Arabia, 2014. Emerg Infect Dis. (2016) 22:49. doi: 10.3201/eid2201.151340

91. Yang J, Zheng Y, Gou X, Pu K, Chen Z, Guo Q, et al. Prevalence of comorbidities in the novel Wuhan coronavirus (COVID-19) infection: a systematic review and meta-analysis. Int J Infect Dis. (2020) 94:91-5. doi: 10.1016/j.ijid.2020.03.017

92. Huang C, Wang Y, Li X, Ren L, Zhao J, Hu Y, et al. Clinical features of patients infected with 2019 novel coronavirus in Wuhan, China. Lancet. (2020) 395:497-506. doi: 10.1016/S0140-6736(20)30183-5

93. Tang N, Li D, Wang X, Sun Z. Abnormal coagulation parameters are associated with poor prognosis in patients with novel coronavirus pneumonia. J Thromb Haemost. (2020) 18:844-7. doi: 10.1111/jth.14768

94. Ai T, Yang Z, Hou H, Zhan C, Chen C, Lv W, et al. Correlation of chest CT and RT-PCR testing in coronavirus disease 2019 (COVID-19) in China: a report of 1014 cases. Radiology. (2020). doi: 10.1148/radiol.2020200642. [Epub ahead of print].

95. Bernheim A, Mei X, Huang M, Yang Y, Fayad ZA, Zhang N, et al. Chest CT findings in coronavirus disease-19 (COVID-19): relationship to duration of infection. Radiology. (2020). doi: 10.1148/radiol.2020200463. [Epub ahead of print].
96. Lei J, Li J, Li X, Qi X. CT imaging of the 2019 novel coronavirus (2019-nCoV) pneumonia. Radiology. (2020) 295:18. doi: 10.1148/radiol.2020200236

97. Yang X, Yu Y, Xu J, Shu H, Xia J, Liu H, et al. Clinical course and outcomes of critically ill patients with SARS-CoV-2 pneumonia in Wuhan, China: a single-centered, retrospective, observational study. Lancet Respir Med. (2020). doi: 10.1016/S2213-2600(20)30079-5. [Epub ahead of print].

98. Rodriguez-Morales AJ, Cardona-Ospina JA, Gutiérrez-Ocampo E, Villamizar-Peña R, Holguin-Rivera Y, Escalera-Antezana JP, et al. Clinical, laboratory and imaging features of COVID-19: a systematic review and meta-analysis. Travel Med Infect Dis. (2020) 34:101623. doi: 10.1016/j.tmaid.2020.101623

99. Lai CC, Shih T-P, Ko W-C, Tang HJ, Hsueh P-R. Severe acute respiratory syndrome coronavirus 2 (SARS-CoV-2) and corona virus disease-2019 (COVID-19): the epidemic and the challenges. Int J Antimicrob Agents. (2020) 55:105924. doi: 10.1016/j.ijantimicag.2020.105924

100. Wang D, Hu B, Hu C, Zhu F, Liu X, Zhang J, et al. Clinical characteristics of 138 hospitalized patients with 2019 novel coronavirus-infected pneumonia in Wuhan, China. JAMA. (2020) 323:1061-9. doi: 10.1001/jama. 2020.1585

101. Richardson S, Hirsch JS, Narasimhan M, Crawford JM, McGinn T, Davidson $\mathrm{KW}$, et al. Presenting characteristics, comorbidities, and outcomes among 5700 patients hospitalized with COVID-19 in the New York City Area. JAMA. (2020). doi: 10.1001/jama.2020.6775. [Epub ahead of print].

102. Grasselli G, Zangrillo A, Zanella A, Antonelli M, Cabrini L, Castelli A, et al. Baseline characteristics and outcomes of 1591 patients infected with SARS-CoV-2 admitted to ICUs of the Lombardy Region, Italy. JAMA. (2020) 323:1574-81. doi: 10.1001/jama.2020.5394

Conflict of Interest: The authors declare that the research was conducted in the absence of any commercial or financial relationships that could be construed as a potential conflict of interest.

Copyright (c) 2020 Tahvildari, Arbabi, Farsi, Jamshidi, Hasanzadeh, Calcagno, Nasiri and Mirsaeidi. This is an open-access article distributed under the terms of the Creative Commons Attribution License (CC BY). The use, distribution or reproduction in other forums is permitted, provided the original author(s) and the copyright owner(s) are credited and that the original publication in this journal is cited, in accordance with accepted academic practice. No use, distribution or reproduction is permitted which does not comply with these terms. 